\title{
Anti-infective properties of medicinal plants from the Baja California peninsula, Mexico for the treatment of Fusarium oxysporum f. sp. basilici in organic sweet basil (Ocimum basilicum)
}

\section{Propiedades anti-infectivas de plantas medicinales de la península de Baja California, México para el tratamiento de Fusarium oxysporum $\mathbf{f}$. sp. basilici en albahaca orgánica (Ocimum basilicum)}

Ramon Jaime Holguín-Peña ${ }^{1}$, Diana Medina-Hernández ${ }^{1}$, Grecia Vázquez-Islas ${ }^{1}$, Francisco Nieto-Navarro ${ }^{2}$, Edgar Omar Rueda Puente ${ }^{3}$

Originales: Recepción: 09/07/2020 - Aceptación: 22/04/2021

\begin{abstract}
Certified-organic farming systems in Baja California Peninsula and Northwest Mexico are nationally and globally recognized, especially due to the production of vegetables and aromatic herbs under protected agriculture systems. Based on the background of some species of the flora of Baja California Sur (BCS) to inhibit a diversity of microorganisms, the effect of 22 medicinal plants of the region was explored to know the in vitro activity against the fungus Fusarium oxysporum f. sp. basilici isolated from basil (Ocimum basilicum L.). The plants processed as crude ethanolic and aqueous extracts were analyzed in duplicate (three replicates) evaluating the inhibition of mycelial growth and spore germination. In mycelial inhibition test, all plants extracts $\left(1000 \mathrm{mg} \mathrm{L}^{-1}\right)$ showed an effectiveness of 11 to $40 \%$ to inhibit $F$ oxysporum. The most effective plant extracts according to $50 \%$ effective inhibition dose $\left(\mathrm{ED}_{50}\right)$, were Larrea tridentata, Hymenoclea monogyra and Lippia palmeri with an $\mathrm{ED}_{50}$ of 220, 303 and $3000 \mathrm{mg} \mathrm{L}^{-1}$, respectively. Tukey's PostHoc tests indicated that $H$. monogyra and L. tridentata are ten times $\left(\mathrm{ED}_{50}<300 \mathrm{mg} \mathrm{L}^{-1}\right)$ more effective than L. palmeri $\left(\mathrm{ED}_{50} 3000\right.$ $\mathrm{mg} \mathrm{L}^{-1}$ ). In addition, the dose-response trend analyzes according to the logarithmic-logistic model ( $d r c$ packages), showed the maximum slope values between 100 and $1000 \mathrm{mg} \mathrm{L}^{-1}$. In the spore germination inhibition tests, most ethanolic extracts (5000 $\left.\mathrm{mg} \mathrm{L}^{-1}\right)$ showed an effectiveness between 21 and $80 \%$. The results of this study demonstrated that the inhibitory potential of these plants used in BCS traditional medicine are a viable alternative for the control of $F$ oxysporum f. sp. basilici in organic basil production systems.
\end{abstract}

Keywords

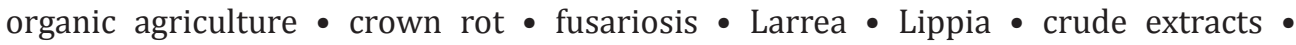
wild oregano $\bullet$ BCS

1 Centro de Investigaciones Biológicas del Noroeste. Programa de Agricultura en Zonas Áridas. Av. Instituto Politécnico Nacional 195. Col. Playa Palo de Santa Rita Sur. C.P. 23096. La Paz. Baja California Sur. México.

2 Tecnológico Nacional de México. Instituto Tecnológico de La Paz. Boulevard Forjadores de B.C.S. 4720. Col. 8 de Octubre 1ra. Sección. C.P. 23080. La Paz. Baja California Sur. México.

3 Universidad de Sonora. Departamento de Agricultura y Ganadería. Boulevard Luis Encinas y Rosales s/n. Col. Centro. C.P. 83000. Hermosillo. Sonora. México.

erueda04@santana.uson.mx 


\section{RESUMEN}

Los sistemas de agricultura orgánica-certificada en la Península de Baja California y el noroeste de México son reconocidos a nivel nacional y mundial, por la producción de verduras y hierbas aromáticas bajo los sistemas de agricultura protegida. Con base en los antecedentes de algunas especies de la flora de Baja California Sur (BCS) para inhibir una diversidad de microrganismos, se exploró el efecto de 22 plantas medicinales de la región para conocer la actividad in vitro contra Fusarium oxysporum f. sp. basilici aislado de la albahaca (Ocimum basilicum L.). Los extractos etanólicos y acuosos crudos se analizaron por duplicado (tres réplicas). En las pruebas de inhibición del crecimiento micelial, todos los extractos (1000 $\mathrm{mg} \mathrm{L}^{-1}$ ) mostraron una efectividad entre el 11 al 40\% para inhibir $F$. oxysporum. Los extractos más efectivos de acuerdo con la dosis efectiva de inhibición al $50 \%\left(\mathrm{ED}_{50}\right)$ fueron Larrea tridentata, Hymenoclea monogyra y Lippia palmeri con una $\mathrm{ED}_{50}$ de 220, 303 y $3000 \mathrm{mg} \mathrm{L}^{-1}$, respectivamente. Las pruebas PostHoc de Tukey indicaron que $H$. monogyra y L. tridentata son diez veces $\left(\mathrm{ED}_{50}<300 \mathrm{mg} \mathrm{L}^{-1}\right)$ más efectivas que L. palmeri $\left(\mathrm{ED}_{50} 3000 \mathrm{mg} \mathrm{L}^{-1}\right)$. Además, los análisis de tendencia dosis-respuesta de acuerdo con el modelo logarítmico-logístico (drc) mostraron los máximos valores de pendiente entre 100 y $1000 \mathrm{mg} \mathrm{L}^{-1}$. En la inhibición de germinación de esporas, la mayoría de los extractos etanólicos (5000 mg L-1) mostraron una efectividad entre 21 y $80 \%$. Los resultados de este estudio demostraron que el potencial inhibitorio de estas plantas utilizadas en la medicina tradicional de BCS son una alternativa viable para el control de la fusariosis causada por $F$. oxysporum f. sp. basilici en los sistemas de producción orgánica de albahaca.

\section{Palabras clave}

agricultura orgánica - pudrición de la corona • fusariosis • Larrea • Lippia • extractos crudos $\bullet$ orégano $\bullet$ BCS

\section{INTRODUCTION}

Sweet basil (Ocimum basilicum L.) is a popular herb used both fresh and dry as flavoring and antioxidant in food and pharmaceutical industries (22). Fresh basil has been the most demanded herb in the United States of America (USA) markets for the gourmet cooking industry, and ranks first among aromatic herbs used by Californian restaurants (4). Most of the basil production takes place in the state of Baja California Sur (BCS) in Mexico, where approximately $700 \mathrm{t}$ are produced by around 200 specialized farms under the certified-organic agriculture scheme (41).

Basil crop is susceptible to a number of fungal diseases caused mainly by two large groups; one related with leaf spots produced by the genera Cercospora, Curvularia and Alternaria, and the second one is related to soil-borne rot diseases caused by the genera Phytophthora, Pythium, Rhizoctonia and Fusarium (33). Thus, fusarium disease can produce wilt and crown rot symptoms, when caused by F. oxysporum f. sp. radicis-lycopersici (FORL) (28), or premature defoliation, vascular wilt and crown rot when associated to F. oxysporum f. sp. basilici (FOB) (20). It is known that the spread of Fusarium in the American continent is so wide. In Argentina, high infection values were observed in soybean seedlings when infected with $F$. graminearum isolated from maize crop residues (5). In Mexico, some variants of $F$. oxysporum have been found associated with corky-root in coffee (19) and several species of Fusarium associated with avocado diseases (31). FOB colonizes the xylem of the host plant, resulting in its blockage and decomposition, with the consequent appearance of the most common and recognizable symptoms, (36). Fusarium disease was widely detected and caused a significant problem in cultivated basil in the USA for two decades. This is currently reported to be one of the most persistent diseases of this crop worldwide (45). Essential oils and tincture preparation are commonly used in a traditional medicine to treat minor infections (10). In organic agriculture, the extracts are commonly utilized as repellants for a wide range of pests (21) and, to a lesser extent, as inhibitors of several pathogenic Fusarium species $(1,9)$.

In BCS, the most important production areas, such as San José del Cabo, Todos Santos and La Paz, different Fusarium species have become the predominant problem in shade mesh or open cultivation (38). This occurs, mainly because the only solvents allowed in organic agri- 
culture are water and ethanol, which necessarily focus on the search for active molecules that may have activity with these solvents. In this sense, a variety of secondary metabolites and diverse compounds of aqueous and ethanolic fractions with antifungal activity have been described (18). However, despite the promising field of research on medicinal extracts with antimicrobial properties for agriculture $(11,24,34)$, most of the ethnobotanical and biological heritage of BCS medicinal plants has focused on their potential use on bacteria and yeasts of clinical interest $(12,26)$.

Aware of the antifungal potential of rained plant resources in the southern part of the Baja California peninsula, the objective of this research was to explore the potential of 22 species of medicinal plants with known antimicrobial activity, as a source of antifungal compounds for the treatment of Fusarium wilt diseases in the production of organic basil in BCS, Mexico.

\section{MATERIALS AND METHODS}

\section{Collection of plant material}

Twenty-two plants used in traditional medicine with antimicrobial properties were selected and collected from different areas of the southern desert region of the Baja California in Mexico. They were grouped according to their traditional behavior and ethnobotanical uses. Table 1 (page 237) summarizes the species name, botanical identification and ethno-pharmaceutical data. The Voucher specimens were deposited in the Herbarium of the Centro de Investigaciones Biológicas del Noroeste (CIBNOR) in La Paz, BCS, México. All plant material was collected during the 2012 rainy season (August to October). The vegetative material was only from leaves that were transported and pressed with a botanical press and dried at room temperature.

\section{Fungus isolation and molecular identification}

Isolation was performed from plants collected in El Pescadero, BCS with symptoms associated with fusariosis disease according to Summerell et al. (2003). The presumptive Fusarium species were characterized based on colony growth on Fusarium-selective medium. Potato dextrose agar (PDA) medium was used to determine colony morphology, growth rates and pigmentation. For the production of chlamydospores, macro- and microconidia, the medium CLA (carnation leaf agar) was used $(43,47)$. For molecular identification, total DNA from the fungus recovery from agar medium was obtained as template in polymerase chain reaction (PCR). One microliter ( $50 \mathrm{ng} \mu \mathrm{L}$ ) of the supernatant was amplified with the primer pair Bik 1 (5'-TTCAAGAGCTAAAGGTCC-3') and Bik 4 (5'-TTTGACCAAGATAGATGCC-3'). PCR conditions were according to the standard procedures for specific detection of FOB (7).

\section{Extracts preparation}

Aqueous and ethanolic extracts were prepared. The aqueous extract was obtained by grinding $10 \mathrm{~g}$ of air-dried powder in $100 \mathrm{~mL}$ of sterile distilled water, which was boiled on slow heat for two hours. The macerate was sieved with a five-layer muslin cloth and centrifuged at $4000 \mathrm{~g}$ for $30 \mathrm{~min}$. The collected supernatant was filtered with Whatman filter paper No. 2 (GE Healthcare, UK) and autoclaved at $121^{\circ} \mathrm{C}$ and $15 \mathrm{lb}$ pressure. The resulting solution of $100 \mathrm{~g} \mathrm{~L}^{-1}$ was considered as mother stock. For ethanol extracts, the leaves were dried at room temperature for two weeks and then ground into powder with a blender. Then, $50 \mathrm{~g}$ of the powdered plant material were soaked in $200 \mathrm{~mL}$ ( $95 \%$ ethanol) at room temperature for five days. Each of the solvent extracts was shaken daily with a shaker for regular infusion. The filtrates obtained were evaporated using a rotary vacuum vapor distillation (Buchi Rotavapor R-114, Labortechnik, AG) at $60{ }^{\circ} \mathrm{C}$, re-suspended in $20 \mathrm{~mL}$ of ethanol and fixed at a concentration with $100 \mathrm{~g} \mathrm{~L}^{-1}$ as maximum in test concentration and stored in sterile glass bottles at $5^{\circ} \mathrm{C}$ until use (12).

\section{Preliminary inhibition screening}

To investigate the inhibition potential of the selected medicinal plants, two different methods were used. The first was the sensi-disc diffusion method (SDD) selected to perform the general screening of the 22 selected plants at $1000 \mathrm{mg} \mathrm{L}^{-1}$. This type of test provided a quick and inexpensive way to obtain reliable quantitative results. The three most active extracts in SDD 
were selected for screening in the agar-dilution method (ADL), which allowed the sample to dissolve the agar. Therefore, its concentration was constant throughout the plate and was used to evaluate the effective doses $\left(E_{50}\right)$ of mycelial growth inhibition in response to $50 \%$ of the expected effect (7). Inoculum concentrations were prepared and adjusted to $10^{6} \mathrm{CFU} \mathrm{mL} \mathrm{m}^{-1}$.

Table 1. Ethnobotanical data of plants collected from the Baja California peninsula in Mexico, according to the ethno-pharmacological use.

Tabla 1. Datos etnobotánicos de las plantas recolectadas de la península de Baja California de México, según el uso farmacológico.

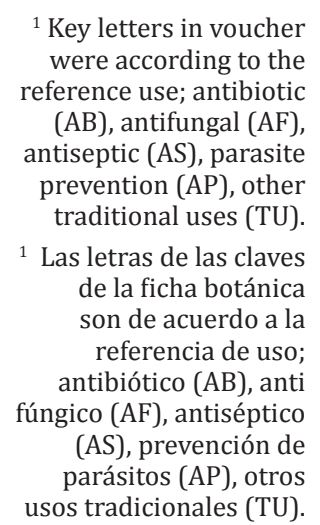

\begin{tabular}{|c|c|c|c|}
\hline Family/plant species & $\begin{array}{l}\text { Common name/ } \\
\text { native name }\end{array}$ & Voucher $^{1}$ & $\begin{array}{c}\text { Ethno pharmacological } \\
\text { uses }\end{array}$ \\
\hline $\begin{array}{l}\text { Anacardiaceae } \\
\text { Cyrtocarpa edulis } \\
\text { (Brandegee) Standley }\end{array}$ & Plum tree/ciruelo del monte & AS-218 & Disinfection of gums \\
\hline $\begin{array}{l}\text { Aristolochiaceae } \\
\text { Aristolachia montícola } \\
\text { Brandegee }\end{array}$ & $\begin{array}{l}\text { Dutchman's pipe/hierba del } \\
\text { indio }\end{array}$ & AP-269 & $\begin{array}{l}\text { Intestinal parasites, } \\
\text { amoeba and skin } \\
\text { infections }\end{array}$ \\
\hline $\begin{array}{l}\text { Asteraceae } \\
\text { Ambrosia ambrosoides (Cav.) } \\
\text { Payne }\end{array}$ & Canyon ragweed/chicura & $\mathrm{AB}-111$ & Antiseptic and antibiotic \\
\hline $\begin{array}{l}\text { Ambrosia ludoviciana subsp } \\
\text { mexicana }\end{array}$ & $\begin{array}{l}\text { Triangle leaf bursage or } \\
\text { donkeybush/estafiate }\end{array}$ & AP-21 & $\begin{array}{l}\text { Amoebae and parasites, } \\
\text { insecticide }\end{array}$ \\
\hline $\begin{array}{l}\text { Anaphalis margaritacea (L.) } \\
\text { Benth. }\end{array}$ & $\begin{array}{l}\text { Western pearly everlasting/ } \\
\text { gordolobo }\end{array}$ & AP-17 & $\begin{array}{l}\text { Stomach parasites, } \\
\text { antiseptic }\end{array}$ \\
\hline Artemisa absinthium L. & $\begin{array}{l}\text { Master herb or ajenjo macho/ } \\
\text { prodigiosa }\end{array}$ & AS-134 & $\begin{array}{l}\text { Antiseptic, parasites and } \\
\text { anthelmintic }\end{array}$ \\
\hline Baccharis glutinosa Pers. & $\begin{array}{l}\text { Douglas' false willow/ } \\
\text { guatamote }\end{array}$ & AS-271 & $\begin{array}{l}\text { Antiseptic for infections } \\
\text { in sores and wounds }\end{array}$ \\
\hline Perityle californica Benth & $\begin{array}{l}\text { Rock daisy/manzanilla del } \\
\text { monte }\end{array}$ & $\mathrm{AB}-250$ & $\begin{array}{l}\text { Preventive of venereal } \\
\text { diseases }\end{array}$ \\
\hline $\begin{array}{l}\text { Haplopappus sonorensis (A. } \\
\text { Gray) S.F. Blake }\end{array}$ & $\begin{array}{l}\text { Haplopappus/hierba del } \\
\text { pasmo }\end{array}$ & AS-46 & $\begin{array}{l}\text { Preventive for minor } \\
\text { infections, antiseptic }\end{array}$ \\
\hline $\begin{array}{l}\text { Trixis californica var. } \\
\text { peninsularis S.F. Blake }\end{array}$ & $\begin{array}{l}\text { California trixis/hierba de } \\
\text { Santa Lucia }\end{array}$ & AP-185 & Stomach parasites \\
\hline $\begin{array}{l}\text { Hymenoclea monogyra Torr. } \\
\text { \& A. Gray. }\end{array}$ & $\begin{array}{l}\text { Singlewhorl or burrobrush/ } \\
\text { romerillo }\end{array}$ & $\mathrm{AB}-47$ & Tetanus disease \\
\hline $\begin{array}{l}\text { Bignonaceae } \\
\text { Crescencia alata Kunth }\end{array}$ & $\begin{array}{l}\text { Calabash or cirian/ } \\
\text { Tecomate }\end{array}$ & AP-131 & Parasites \\
\hline $\begin{array}{l}\text { Boraginaceae } \\
\text { Borago officinalis L. }\end{array}$ & $\begin{array}{l}\text { Borege or cooltankard } \\
\text { tailwort/borraja }\end{array}$ & $\mathrm{AB}-345$ & Measles and smallpox \\
\hline $\begin{array}{l}\text { Heliotropium curassavicun } \\
\text { (L.) var. oculatum (Heller) }\end{array}$ & $\begin{array}{l}\text { Wild heliotrope/hierba del } \\
\text { sapo, berro, María Luisa }\end{array}$ & AS-23 & $\begin{array}{l}\text { Antiseptic and to wash } \\
\text { bounds }\end{array}$ \\
\hline $\begin{array}{l}\text { Euphorbiaceae } \\
\text { Acalypha comonduana Mill. }\end{array}$ & $\begin{array}{l}\text { Cooper leaf/hierba } \\
\text { sanalotodo }\end{array}$ & AP-150 & Parasites and antiseptic \\
\hline Ricinus communis L. & Castor beans/higuerilla & AS-179 & $\begin{array}{l}\text { Antiseptic, antibiotic, } \\
\text { acaricidal, insecticidal }\end{array}$ \\
\hline Euphorbia nutans (Lag.) & $\begin{array}{l}\text { Nodding spurge/ } \\
\text { hierba golondrina }\end{array}$ & AP-38 & Parasites \\
\hline $\begin{array}{l}\text { Jatropha cinérea (Ortega) } \\
\text { Muell.-Arg. }\end{array}$ & $\begin{array}{l}\text { Arizona nettlespurge/ } \\
\text { lomboy }\end{array}$ & AS-27 & Antiseptic \\
\hline $\begin{array}{l}\text { Nyctaginaceae } \\
\text { Mirabilis jalapa L. }\end{array}$ & $\begin{array}{l}\text { Common four o'clock/ } \\
\text { maravilla }\end{array}$ & AS-52 & Infected wounds \\
\hline $\begin{array}{l}\text { Pedaliaceae } \\
\text { Proboscidea althaefolia } \\
\text { (Roxb) Benth }\end{array}$ & $\begin{array}{l}\text { Desert unicorn/espuela del } \\
\text { diablo, }\end{array}$ & AS-161 & $\begin{array}{l}\text { For the treatment of } \\
\text { infected wounds }\end{array}$ \\
\hline $\begin{array}{l}\text { Verbenaceae } \\
\text { Lippia palmeri S. Watson }\end{array}$ & $\begin{array}{l}\text { Wild or Mexican oregano/ } \\
\text { oregano del monte }\end{array}$ & $\mathrm{AF}-44$ & Antimicrobial \\
\hline $\begin{array}{l}\text { Zygophyllacceae } \\
\text { Larrea tridentata (Seesé \& } \\
\text { Moc. Ex D.C.) }\end{array}$ & $\begin{array}{l}\text { Creosote bush or governor/ } \\
\text { gobernadora, oamis }\end{array}$ & AS-501 & Parasites, antiseptic \\
\hline
\end{tabular}




\section{Sensi-disc diffusion (SDD) method}

After preparing the PDA medium, F oxysporum strains were incubated at $25{ }^{\circ} \mathrm{C}$ to allow mycelial development from seven to 10 days. Consequently, six-millimeter cylindrical sections (explants) were cut from the fungal-medium, and used as inoculum for testing. The explant containing the test microorganism was inoculated in the center of the previously prepared sterile agar bed $(15 \mathrm{~mL})$ and contained in the Petri dishes. Radially, four diffusion paper discs $(0.5 \mathrm{~cm}$ in diameter) were placed on each agar plate previously impregnated with $1000 \mathrm{mg} \mathrm{L}^{-1}$ of each extract. Subsequently, the diameters of the inhibition zones were measured, and the inhibition percentage of radial growth was calculated. Growth inhibition was established in ranges with values from 0.1 to $10 \%(-), 11$ to $20 \%( \pm), 21$ to $40 \%(+), 41$ to $80 \%(++)$ and values $\geq 81 \%(+++)$.

\section{Agar dilution method (ADL)}

The best treatments for SDD with an activity between 21 and $40 \%(++)$ in all the tests evaluated were tested by the ADL method to obtain $\mathrm{ED}_{50}$ and $\mathrm{ED}_{90}$. The doses were determined logarithmically based on 2,4 and $8(20,40,80,200,400,800,2000,4000,8000$ and $20000 \mathrm{mg} \mathrm{L}^{-1}$ ). The plates were inoculated at the center with $5 \mathrm{~mm}$ of fungal culture disc and then incubated at $28{ }^{\circ} \mathrm{C}$ for seven days. The effectivity of the extracts was calculated as mycelial growth inhibition using the formula inhibition percentage $(\%)=[$ control growthsample growth) / (control growth) x 100]. As controls, $0.1 \%$ benomyl (1000 $\mathrm{mg} \mathrm{L}^{-1}$ ) was used according to the in vitro doses of systemic (250 to $1000 \mathrm{mg} \mathrm{L}^{-1}$ ) and non-systemic fungicides (1000 to $\left.2000 \mathrm{mg} \mathrm{L}^{-1}\right)(29)$. Treatments using only ethanol and water ( $1 \mathrm{mg} \mathrm{mL}^{-1}$ each) were included in the controls. The treatments had four repetitions and were carried out in duplicate.

\section{Spore germination inhibition}

Based on the literature, spore germination inhibition studies were carried out by the ADL method using only the ethanol plant extracts (29). The stock solutions (S) were prepared as ethanolic extracts at a concentration of $5 \mathrm{mg} \mathrm{mL}^{-1}$. Fungal spores $(\sim 500)$ from one-weekgrowing cultures, together with one drop of each plant extract at each concentration, were placed on a glass slide and incubated $\left(25 \pm 2{ }^{\circ} \mathrm{C}\right)$ for $24 \mathrm{~h}$. The spores were stained with cotton blue and mounted in lactophenol; $100 \mu \mathrm{L}$ were placed in a Neubauer chamber (Celeromics, Grenoble, FR) and observed under a light microscope. Inhibition percentage was calculated with the formula: percentage of spore germination inhibition (SGI) $=[(\mathrm{A}-\mathrm{B}) / \mathrm{A})$ $x 100$, where $A=$ Number of germinated spores in the control-number of germinated spores in the treatment, $B=$ number of germinated spores in control (42).

\section{Statistical analysis}

The dose-response analysis was performed with a generalized log-logistic model using R Statistical Computing of $d r c$ packages (40). To fit the dose-response model, $\mathrm{ED}_{50}$ was determined according to the three-parameter log-logistic function (LL.3) where the lowest limit was zero. Data were expressed as the mean $( \pm S E)$. The lack-of-fit was determined by one-way analysis of variance (ANOVA). Tukey HSD test was used for multiple comparisons between treatments (extracts) with a previous evaluation of normality (Shapiro-Wilks test) and homogeneity of variance (Levene's test). Statistical significance in spore germination was analyzed by Student's t-test. All experiments were conducted in duplicate.

\section{RESULTS AND DISCUSSION}

\section{Fungus identification and disease determination}

The fungus, consistently isolated from the vascular tissue, was preliminarily confirmed as $F$. oxysporum based on the morphological characteristics of the mycelia and conidia grown in CLA medium. The characteristics that describe the species were observed, from the pale pink pigmentation of the mycelium to the observation of microconidia, macroconidia and globose chlamydospores (47). The pathogenic fungus was identified as Fusarium oxysporum f. sp. basilici based on the specific amplification of the expected $943 \mathrm{bp}$ with Bik 1 and Bik 4 primers. No amplification was obtained from DNA extracted from healthy seedlings. In addition, the symptoms of vascular wilt, crown and root rot observed in the field were similar to those reported in other basil production systems in the world $(17,36,37,46)$. 
${ }^{1}$ The inhibition symbology $(-,+)$ in the table was according the observed ranges: $(-) \leq$ $10 \%$ growth inhibition,

(士) 11 to $20 \%,(+) 21$ to $40 \%,(++) 41$ to $80 \%$, and $(+++) \geq 81 \%$ $(n=6) \cdot{ }^{2}$ All extracts for mycelial inhibition were extracted from the leaves at standard concentrations of $1000 \mathrm{mg} \mathrm{L}^{-1} \cdot{ }^{3}$ Spore germination inhibition test was carried out at concentrations of $5 \mathrm{mg} \mathrm{mL}^{-1}$.

${ }^{1}$ La simbología de inhibición en la tabla $(-,+)$ es de acuerdo a los rangos observados: $(-) \leq 10 \%$ de inhibición del crecimiento, $( \pm) 11$ a $20 \%,(+) 21$ a $40 \%$, $(++) 41$ a $80 \%$ y (+++) $\geq 81 \%(\mathrm{n}=6) .{ }^{2}$ Todos los extractos para la inhibición del micelio fueron extraídos de las hojas a concentraciones estándar de $1000 \mathrm{mg} \mathrm{L}^{-1}$.

${ }^{3}$ La prueba de inhibición de la geminación de esporas se realizó a una concentración de $5 \mathrm{mg} \mathrm{mL}^{-1}$.

\section{In vitro screening of mycelial growth activity}

Most of the aqueous-ethanol extracts tested in initial screening by SDD method showed an inhibition effectiveness similar to those reported with other filamentous fungi worldwide $(7,8,11,15,18,28,30)$ with inhibition ranges between $1000 \mathrm{mg} \mathrm{L}^{-1}$ for mycelial growth $(29,42)$. Table 2 shows that all selected plants $(24)$ showed at least moderate activity (21 to $40 \%$ ) in mycelial growth. Among the most promising crude extracts with potential to be used in organic agriculture against $F$. oxysporum were L. tridentata, H. monogyra and L. palmeri, with mostly inhibitions from $41(++)$ to $\geq 81 \%(+++)$ with water and ethanol solvents $\left(1000 \mathrm{mg} \mathrm{L}^{-1}\right)$. The next most effective plants with values from 21 to $40 \%$ were Aristolachea montícola, Cyrtocarpa edulis, Haplopappus sonorensis and Ambrosia ambrosoides. The ethanol extracts of these selected plants significantly showed higher activity compared to aqueous extracts. Thus, ethanol and aqueous extracts with the highest activity were selected for further analysis of $50 \%$-effective doses $\left(E D_{50}\right)$ and spore inhibition tests.

Table 2. In vitro screening of mycelial radial growth and spore germination inhibition of the most effective extracts by the SDD method against Fusarium oxysporum f. sp. basilici after six days.

Tabla 2. Detección in vitro del crecimiento radial micelial y la inhibición en la germinación de esporas mediante el método SDD contra Fusarium oxysporum f. sp. basilici después de seis días.

\begin{tabular}{|c|c|c|c|}
\hline \multirow{3}{*}{ Plant species } & \multicolumn{3}{|c|}{ Range of inhibition (\%) ${ }^{1}$} \\
\hline & \multicolumn{2}{|c|}{$\begin{array}{l}\text { Radial growth } \\
\text { mycelium }^{2}\end{array}$} & \multirow{2}{*}{$\begin{array}{l}\text { Spores }^{3} \\
\text { Ethanol }\end{array}$} \\
\hline & Ethanol & Water & \\
\hline Larrea tridentata & ++ & ++ & +++ \\
\hline Hymenoclea monogyra & ++ & + & +++ \\
\hline Lippia palmeri & ++ & ++ & ++ \\
\hline Trixis californica var. peninsularis & + & $+/-$ & +++ \\
\hline Aristolachia montícola & $+/-$ & $+/-$ & + \\
\hline Cyrtocarpa edulis & $+/-$ & $+/-$ & $+/-$ \\
\hline Haploppapus sonorensis & + & $+/-$ & + \\
\hline Ambrosia ambrosoides & $+/-$ & $+/-$ & $+/-$ \\
\hline Baccharis glutinosa & $+/-$ & - & + \\
\hline Crescencia alata & $+/-$ & - & $+/-$ \\
\hline Artemisia absinthium & + & - & $+/-$ \\
\hline Heliotropium curassavicun & $+/-$ & $+/-$ & ++ \\
\hline Ricinus communis & $+/-$ & $+/-$ & - \\
\hline Euphorbia nutans & $+/-$ & $+/-$ & ++ \\
\hline Jatropha cinérea & $+/-$ & - & + \\
\hline Mirabilis jalapa & $+/-$ & - & + \\
\hline Proboscidea althaefolia & - & + & ++ \\
\hline Acalypha comonduana & - & + & + \\
\hline Anaphalis margaritacea & $+/-$ & + & - \\
\hline Borago officinalis L. & $+/-$ & + & - \\
\hline Ambrosia ludoviciana (Cav.) Payne & $+/-$ & + & - \\
\hline Perityle californica Benth & + & + & - \\
\hline Benomyl (1000 $\left.\mathrm{mg} \mathrm{L}^{-1}\right)$ & +++ & +++ & +++ \\
\hline Control 1 (ethanol 70\%) & - & - & - \\
\hline Control 2 (water) & - & - & - \\
\hline
\end{tabular}

\section{Spore germination inhibition analysis}

At least 17 plant extracts showed some inhibitory effect from 11 to $20 \%$ at low doses of $5 \mathrm{mg} \mathrm{mL}^{-1}$. (table 2). The best treatments for the inhibition of the fungus were L. tridentata, H. monogyra and Trixis peninsularis. They were the most effective with inhibition above $81 \%(+++)$. Similar response at $5 \mathrm{mg} \mathrm{mL}^{-1}$ has been observed in other ethanol extracts against the in vitro F. oxysporum test $(6,29)$. The extracts of L. palmeri, Heliotropium curassavicun, Euphorbia nutans and Proboscidea althaefolia showed an inhibition of sporulation 
in a range from 41 to $80 \%$, although the effect on mycelial inhibition was moderate (11 to $20 \%$ ). The tendency of progressive increase in sporulation inhibition with the increase of concentrations was also observed (table 2, page 239).

\section{Effectiveness of dose response $\left(\mathrm{ED}_{50}\right)$}

Model parameters of $\mathrm{ED}_{50}$ indicated $50 \%$ of effective biocontrol (dose-response). $\mathrm{ED}_{50}$ response of the most effective plant extracts by the ADL method were L. tridentata, $H$. monogyra and L. palmeri with values ranging from 220 to $3000 \mathrm{mg} \mathrm{L}^{-1}$ (table 3). The three tested extracts showed significant differences among the effective doses (one-way ANOVA, $\mathrm{F}=136.6, P<0.001$ ). The PostHoc Tukey HSD test indicated that $\mathrm{ED}_{50}$ of the L. tridentata $\left(\mathrm{ED}_{50}=220 \mathrm{mg} \mathrm{L}^{-1}\right.$ and $\mathrm{H}$. monogyra $\left(\mathrm{ED}_{50}=303 \mathrm{mg} \mathrm{L}^{-1}\right)$ were more efficient to inhibit the fungus (figure 1A, page 241). The predictive trend of the three extract curve analysis, focusing on dose-response at the logarithmical concentration studied (10-10000 mg L-1), were more pronounced in L. tridentata than H. monogyra and L. palmeri (figure 1B, page 241). However, no significant differences were observed between $\mathrm{ED}_{50}$ of L. tridentata and $H$. monogyra $(P>0.05)$. This result indicated that $L$. tridentata was 13.6 times more effective than L. palmeri and 1.3 times more than H. monogyra.

Table 3. Percentage of inhibition of the radial mycelial growth of Fusarium oxysporum f. sp. basilici of the extracts with the highest antimicrobial activity in the SDD tests, showing the effective dose $\left(\mathrm{ED}_{50}\right)$, logarithmical concentration and the fiducial limits

Tabla 3. Porcentaje de inhibición del crecimiento radial micelial de Fusarium oxysporum f. sp. basilici de los extractos con mayor actividad en las pruebas SDD, mostrando la dosis efectiva $\left(E D_{50}\right)$, las concentraciones logarítmicas y los límites fiduciales.

${ }^{1}$ ED50 = effective dose which inhibits 50\% of the population.

${ }^{2}$ Fiducial limits of the standard error $( \pm)$ adjusted to the ANOVA model $(\mathrm{P}>0.05)$.

${ }^{1}$ ED50= dosis efectiva para inhibir el 50\% de la población. ${ }^{2}$ Limites fiduciales del error estándar ( \pm ) ajustado al modelo ANOVA $(\mathrm{P}>0,05)$.

\begin{tabular}{|c|c|c|c|}
\hline \multirow{2}{*}{$\begin{array}{c}\text { Logarithmical } \\
\text { concentration } \\
\text { (mg L }^{-1} \text { ) }\end{array}$} & \multicolumn{3}{|c|}{ Mycelial radial inhibition (\%) } \\
\cline { 2 - 4 } & Lippia palmeri & $\begin{array}{c}\text { Larrea } \\
\text { tridentata }\end{array}$ & $\begin{array}{c}\text { Hymenoclea } \\
\text { monogyra }\end{array}$ \\
\hline 40 & $5.25 \pm 0.4$ & $33.91 \pm 1.74$ & \\
\hline 60 & $10.36 \pm .38$ & & $30.78 \pm 0.68$ \\
\hline 80 & $9.69 \pm 0.86$ & $42.81 \pm 1.13$ & $36.02 \pm 0.93$ \\
\hline 200 & $14 \pm 0.23$ & $52.66 \pm 1$ & $46.77 \pm 0.81$ \\
\hline 400 & $26.65 \pm 0.81$ & $65.16 \pm 2.11$ & $54.3 \pm 0.94$ \\
\hline 600 & $32.97 \pm 0.59$ & $73.28 \pm 0.66$ & $59.01 \pm 1.06$ \\
\hline 800 & $40.38 \pm 0.36$ & $78.25 \pm 0.9$ & $63.98 \pm 0.51$ \\
\hline 2000 & $53.97 \pm 3.01$ & $87.81 \pm 0.37$ & $73.12 \pm 1.09$ \\
\hline 4000 & $68.64 \pm 3.52$ & 100 & $79.03 \pm 1.69$ \\
\hline 6000 & $79.27 \pm 0.45$ & 100 & $84.54 \pm 0.41$ \\
\hline 8000 & $85.87 \pm 0.61$ & 100 & $84.11 \pm 1.07$ \\
\hline $\mathrm{ED}_{50}{ }^{1}$ & $3000.28 \pm 979.75$ & $220.87 \pm 31.01$ & $303.46 \pm 33.73$ \\
\hline$P$ & 0.008 & 0.0022 & 0.0026 \\
\hline & & & \\
\hline
\end{tabular}

The $\mathrm{ED}_{50}$ of the BCS plant extracts were lower than those of other of similar reported species (Origanum spp.), extracted as essential oils, where $\mathrm{ED}_{50}$ was from 450 to $8000 \mathrm{mg}$ $\mathrm{L}^{-1}(3)$. The literature has reported that the effectiveness in vitro of the aqueous-ethanol extracts of medicinal plants has a wide range from 100 to $5000 \mathrm{mg} \mathrm{L}^{-1}$ to inhibit fungi of different genus; Aspergillus, Colletotrichum, Phytophthora, Penicillium, Botrytis, Alternaria and Fusarium $(15,35)$. On the other hand, the formulation of botanical fungicides with good potential to inhibit a wide range of filamentous fungi ranges from 1000 to $2000 \mathrm{mg} \mathrm{L}^{-1}(44)$. In spore germination assays, the extracts of L. tridentata, H. monogyra and T. peninsularis were the most effective to inhibit spore germination at $5000 \mathrm{mg} \mathrm{L}^{-1}$ by more than $81 \%$, followed by the extracts of L. palmeri, H. curassavicun and P. althaefolia, which presented values of 41 to $80 \%$ (table 2, page 239). The results of this study were in agreement with Obongoya et al. (2010) who showed the phytotoxic effect selecting crude extracts of some Mexican plants against soil-borne F. oxysporum f. sp. phaseoli ranging from 2.5 to $10 \mathrm{mg} \mathrm{mL}^{-1}$. 
Tukey's PostHoc test indicated that $H$. monogyra and $L$. tridentata are more effective $\left(\mathrm{ED}_{50}<500 \mathrm{mg}\right.$ $\left.\mathrm{L}^{-1}\right)$ than L. palmeri $\left(\mathrm{ED}_{50}\right.$ $\sim 3000 \mathrm{mg} \mathrm{L}^{-1}$ ). B. Trend line due to the effect of logarithmic doses $(20$, $40,60,80,200,400,600$, $800,2000,4000,6000$, $8000 \mathrm{mg} \mathrm{L}^{-1}$ ), observing the most marked effect among the 100 and $1000 \mathrm{mg} \mathrm{L}^{-1}$ ).

La prueba PostHoc de Tukey indicó que la $H$. monogyra y L. tridentata son más efectivos

$\left(\mathrm{ED}_{50}<500 \mathrm{mg} \mathrm{L}^{-1}\right)$ que L. palmeri $\left(\mathrm{ED}_{50} \sim 3000\right.$ $\left.\mathrm{mg} \mathrm{L}^{-1}\right)$. B. Línea de tendencia por efecto de las dosis logarítmicas $(20,40,60,80,200,400$, $600,800,2000,4000$, $6000,8000 \mathrm{mg} \mathrm{L}^{-1}$ ), observándose el efecto más marcado entre los 100 y $1000 \mathrm{mg} \mathrm{L}^{-1}$ ).
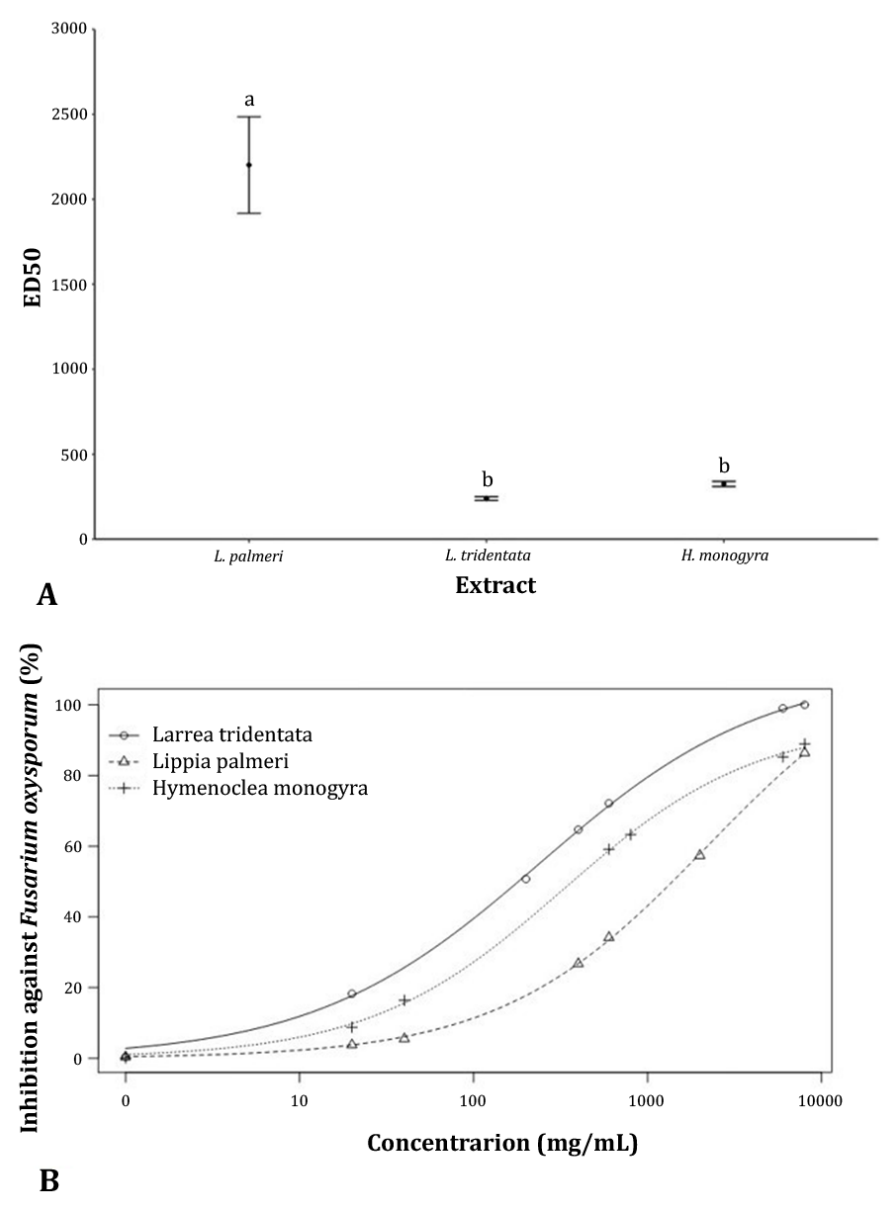

Figure 1. Dose-response of inhibition of ethanol-aqueous extracts of medicinal plants from BCS, Mexico with greater antimicrobial activity against Fusarium oxysporum f. sp. basilici. A.

Figura 1. Dosis-respuesta de inhibición de los extractos etanólicos-acuosos de plantas medicinales de BCS, México con mayor actividad antimicrobiana contra de Fusarium oxysporum f. sp. basilici. A.

This research showed that three species used in traditional medicine in BCS could potentially control fusarium disease. However, for this particular species (F oxysporum $\mathrm{f}$. sp. basilici), very few studies have documented the antifungal activity, and the most documented are especially related to antimicrobial activity with some bacteria of clinical interest $(12,26)$. By far, L. tridentata locally known as "gobernadora" (governor), creosote bush or chaparral, is one of the most documented species with inhibitory effects. For approximately half a century, L. tridentata has been the most studied plant in Mexico and the world and reported for the treatment of more than 50 diseases (2). The effect of this species as anti-parasitic, antiseptic and control of foot fungi and bacteria and treatment of kidney and gynecological infections are well documented (16). One of the most active ingredients, nordhydroguaiaretic acid (NDGA) and numerous lignans have been characterized. This species was found to be the most promising in this study based on values of $220 \mathrm{mg} \mathrm{L}^{-1}$ and values $\geq 81 \%$ to inhibit sporulation at $1000 \mathrm{mg} \mathrm{L}^{-1}$. Oregano is one of the most interesting cases from its nomenclature, which can be referred to as Mexican or wild oregano (L. palmeri, Verbenaceae family) or in the world known as common oregano (Origanum vulgare; Lamiaceae family). The microbial properties of both species are well documented, and it appears to be an interesting promise because of its availability as an agricultural domesticated species $(27,32)$. In addition to their wide use in the food industry, active compounds, such as eugenol, carvacrol, carvone, p-cymene and thymol inhibit mycelial growth and sporulation of different types of Fusarium species in a variety of crops (13). The effectiveness of 
L. palmeri as an aqueous-ethanol extract has been observed in other medicinal and culinary plants in the state of BCS, such as sage (Salvia officinalis) and where this type of extraction maximizes antifungal components (10). On the other hand, its multiple use as an export crop (41) could be interesting for the industry as essential oil or dry for the food industry or for the formulation of natural antifungal solutions for agricultural use (8). Hymenoclea monogyra seems to be the least documented; however, different species of the genus have shown antimicrobial properties due to the presence of flavonoids and sesquiterpene lactones. $H$. monogyra has been reported against enteropathogenic bacteria in BCS and in other regions of northwest Mexico (25). A diversity of active compounds can be extracted from medicinal plants using ethanol-water methods, which makes it an interesting model for the semi-pilot scale extractions, providing confidence for the optimization processes in the formulation of botanical fungicides.

Mexico is a country with an agricultural vocation where certified agriculture activities in the production of vegetables and aromatic herbs occur mainly in the states of Sinaloa, Sonora and BCS (23). The most important regions of the peninsula are mainly in Ensenada, which is the largest municipality with an organic agricultural vocation. Other producing areas in the southern part of the peninsula, such as Santo Domingo, Valle de Vizcaino, La Paz and San Jose del Cabo are known for the production of annual vegetables and for the certified organic production of aromatic herbs (14). Basil is the most commercialized gourmet herb species that generates a good economic performance (39). Although losses due to fusarium in this crop have not been estimated in BCS, the pressure of the disease and the lack of botanical fungicides for its control are a constant risk for production systems. This study has reported F. oxysporum f. sp. basilici associated with crown and root rot and wilt diseases in basil grown in BCS for the first time. Crude aqueous-ethanol extracts of L. tridentata, L. palmeri and H. monogyra, can efficiently inhibit mycelial growth and spore germination of F. oxysporum f. sp. basilici with potential use in phytosanitary management programs for organic basil production.

\section{ConClusions}

The in vitro effectiveness of Fusarium-growth inhibition $\left(\mathrm{ED}_{50}\right.$ ranges from 220 to 3000 $\left.\mathrm{mg} \mathrm{L}^{-1}\right)$ and inhibition of sporulation (80\% at doses of $5000 \mathrm{mg} \mathrm{L}^{-1}$ ) of native medicinal plants (L. tridentata, H. monogyra and L. palmeri) from the Baja California peninsula, opens the possibility of using them as an ethanol-aqueous extract for long-term control of the fusarium disease caused by F. oxysporum f. sp. basilici in organic basil in BCS, Mexico and in other producing areas of the world.

\section{REFERENCES}

1. Akladious, S. A.; Isaac, G. S.; Abu-Tahon, M. A. 2014. Induction and resistance against fusarium wilt disease of tomato by using sweet basil (Ocimum basilicum L.) extract. Canadian Journal of Plant Sciences. 95: 689-701. Doi: 10.4141/CJPS-2014-127.

2. Arteaga, S.; Andrade-Cetto, A.; Cárdenas, R. 2005. Larrea tridentata (creosote bush), an abundant plant of Mexican and US-American deserts and its metabolite nordihydroguaiaretic acid. Journal of Ethnopharmacology. 98: 231-239.

3. Bakkali, F.; Averbeck, S.; Averbeck, D.; Idaomar, M. 2008. Biological effects of essential oils-A review. Food and Chemical Toxicology. 46: 446-475.

4. Beltrán-Morales, A.; Ruiz-Espinoza, F. H.; Loya-Ramírez, J. G.; Murillo-Amador, B.; Zamora-Salgado, S.; Beltrán-Morales, J. A.; Troyo-Diéguez, E.; García-Hernández, J. L. 2010. Situación actual y perspectivas en la producción de hierbas aromáticas orgánicas en Baja California Sur. In: García-Hernández J. L.; Salazar-Sosa, E.; Orona-Castillo, I.; Fortis-Hernández, M.; Trejo Escareño, H. I. (eds.). Agricultura orgánica, tercera parte. Universidad Juárez del Estado de Durango, México. 350-368 p.

5. Bonacci, M.; Barros, G. 2019. Genetic diversity and pathogenicity on root seedlings from three soybean cultivars of Fusarium graminearum isolated from maize crop residues. Revista de la Facultad de Ciencias Agrarias Universidad Nacional de Cuyo. Mendoza. Argentina. 51(1): 147-160.

6. Breda, C. A.; Gasperini, A. M.; García, V. L.; Monteiro, K. M.; Bataglion, G. A.; Eberlin, M. N.; Duarte, M. C. T. 2016. Phytochemical analysis and antifungal activity of extracts from leaves and fruit residues of Brazilian savanna plants aiming its use as safe fungicides. Natural Products Bioprospecting. 6: 195-204. 
7. Chiocchetti, A.; Sciaudone, L.; Durando, F.; Garibaldi, A.; Migheli, Q. 2007. PCR Detection of Fusarium oxysporum f. sp. basilici on Basil. Plant Disease. 85: 607-611.

8. Cos, P.; Vlietinck, A. J.; Berghe, D. V.; Maes, L. 2006. Anti-infective potential of natural products: How to develop a stronger in vitro 'proof-of-concept'. Journal of Ethnopharmacology, 106: 290-302.

9. Dissanayake, M. L. M. C. 2013. Inhibitory effect of selected medicinal plant extracts on phytopathogenic fungus Fusarium oxysporum (Nectriaceae) Schlecht. Emend. Snyderand Hansen. Annual Research and Review in Biology, 4: 133-142. Doi.org/10.9734/ARRB/2014/5777

10. Durling, N. E.; Catchpole, O. J.; Grey, J. B.; Webby, R. F.; Mitchell, K. A.; Foo, L. Y.; Perry, N. B. 2007. Extraction of phenolic and essential oil from dried sage (Salvia officinalis) using ethanolwater mixtures. Food Chemistry, 101: 1417-1424.

11. El-Ghany, A.; Roushd, M. M.; Mohamed, A. A. 2015. Efficacy of certain plant extracts as safe fungicides against phytopathogenic and mycotoxigenic fungi. Agricultural Biological Science Journal. 1: 71-75.

12. Encarnación-Dimayuga, R.; Virgen, M.; Ochoa, N. 1998. Antimicrobial activity of medicinal plants from Baja California Sur (México). Pharmacology Biology. 36: 33-43.

13. Estrada-Cano, C.; Castro, M. A.; Muñoz-Castellanos, L.; Amaya-Olivas, N.; García-Triana, A.; Hernández-Ochoa, L. 2017. Antifungal activity of micro capsulated clove (Eugenia caryophyllata) and Mexican oregano (Lippia berlandieri) essential oils against Fusarium oxysporum. Journal of Microbial and Biochemical Technology. 9: 567-571.

14. Fenech-Larios, L.; Ruiz-Espinoza, F. H.; García-Hernández, J. L.; Murillo-Amador, B.; Gonzales Ocampo, H. A.; Beltrán-Morales, F. A.; Fraga-Palomino, H. 2008. Analysis of agronomic variables of Ocimum basilicum L. under alternative tillage systems and standard organic practices. Tropical and Subtropical Agroecosystems. 8: 157-163.

15. Hernández-Castillo, F. D.; Castillo-Reyes, F.; Gallegos-Morales, G.; Rodríguez-Herrera, R.; Aguilar, C. N. 2011. Plant extracts from Mexican native species: an alternative for control of plant pathogens. In: Research in Organic Farming, InTech. United Kingdom. 139-156 p.

16. Heron, S.; Yarnell, E. 2004. The Safety of low-dose Larrea tridentata (DC) Coville (creosote bush or chaparral): A retrospective clinical study. The Journal of Alternative and Complementary Medicine. 7(2). Doi.org/10.1089/107555301750164262

17. Katan, T.; Gamliel, A.; Katan, J. 1996. Vegetative compatibility of Fusarium oxysporum from sweet basil in Israel. Plant Pathology, 45: 656-661.

18. Lopez-Benitez, A. 2005. Inhibition of mycelial growth of Fusarium oxysporum Schlechtend. f. sp. lycopersici (Sacc.) Snyder y Hansen, Rhizotocnia solani Kühn and Verticilllium dahliae Kleb. through aqueous vegetable extracts. Revista Mexicana de Fitopatología, 28: 183-190.

19. López-Lima, D.; Carrión, G.; Sánchez-Nava, P.; Desgarennes, D.; Villain, L. 2020. Fungal diversity and Fusarium oxysporum pathogenicity associated with coffee corky-root disease in Mexico. Revista de la Facultad de Ciencias Agrarias Universidad Nacional de Cuyo. Mendoza. Argentina. 52(1): 276-292.

20. López-Reyes, J. G.; Gilardi, G.; Garibaldi, A.; Lodovica-Gullino, M. 2016. In vivo evaluation of essential oils and biocontrol agents combined with heat treatments on basil CV Genovese Gigante seeds against Fusarium oxysporum f. sp. basilici. Phytoparasitica. 44: 35-45.

21. Lubbe, A.; Verpoorte, R. 2011. Cultivation of medicinal and aromatic plants for specialty industrial materials. Industrial Crops and Products. 34: 785-801.

22. Makri, O.; Kintzios, S. 2008. Ocimum sp. (basil): Botany, cultivation, pharmaceutical properties, and biotechnology. Journal of Herbs, Spices and Medicinal Plants. 13: 123-150.

23. Marsh, R.; Runsten, D. 2000. The organic produce niche market: can Mexican smallholders be stakeholder? North American Integration and Development Center, UCLA, Los Angeles. CA. USA. p. 1-34.

24. Meraji, H. S.; Mohammadi, M; Seyfi, K. S.; Hazbipour, S.; Moradi, M. 2018. Control of two species of fusarium fungi by medicinal plants. Plant Protection Journal, 9: p. Pe45-Pe57, En 58 ref. 39.

25. Moreno-Salazar, S. F.; Enríquez-Verdugo, A.; Cuama-Lopez, C.; Bolado-Martínez, E.; Medrano Candelas, T.; Robles-Zepeda, R. E. 2008. Activity of medicinal plants, used by native populations from Sonora, Mexico, against enteropathogenic bacteria. Pharmaceutical Biology. 46: 732-737.

26. Murillo-Álvarez, J. I.; Encarnación-Dimayuga, R.; Franzblau, S. G. 2001. Antimicrobial and cytotoxic activity of some medicinal plants from Baja California Sur (México). Pharmaceutical Biology. 39: 445-449.

27. Navarro, V.; Villarreal, M. L.; Rojas, G.; Lozoya. X. 1996. Antimicrobial evaluation of some plants used in Mexican traditional medicine for the treatment of infectious diseases. Journal of Ethnopharmacology. 53: 143-147.

28. Nezfi, A.; Jabnoun-Khiareddine, H.; Abdallah, R. A. B.; Ammar, N.; Medimagh-Saidana, S.; Haouala, R.; Daami-Remadi, M. 2017. Suppressing fusarium crown and root rot infections and enhancing the growth of tomato plants by Lycium arabicum Schweinf. Ex Boiss. Extracts. South African Journal of Botany. 113: 288-299. Doi.org/10.1016/j.sajb.2017.09.002.

29. Nisa, T. U.; Wani, A. H.; Bhat, M. Y.; Pala, S. A.; Mir, R. A. 2011. In vitro inhibitory effect of fungicides and botanicals on mycelial growth and spore germination of Fusarium oxysporum. Journal of Biopesticides. 4: 53-56.

30. Obongoya, B. O.; Wagai, S. O.; Odhiambo. G. 2010. Phytotoxic effect of selected crude plant extracts on soil-borne fungi of common bean. African Crop Science Journal. 18: 15-22. 
31. Olalde Lira, G. G.; Raya Montaño, Y. A.; Apáez Barrios, P.; Vargas-Sandoval, M.; Pedraza Santos, M. E.; Raymundo, T.; Valenzuela Garza, R.; Lara-Chávez, M. B. N. 2020. Characterization of Fusarium spp., A Phytopathogen of avocado (Persea americana Miller var. drymifolia (Schltdl. and Cham.)) in Michoacán, México. Revista de la Facultad de Ciencias Agrarias Universidad Nacional de Cuyo. Mendoza. Argentina. 52(2): 301-316.

32. Ortega-Nieblas, M. M.; Robles-Burgueño, M. R.; Acedo-Félix, E.; González-León, A.; Morales-Trejo, A.; Vázquez-Moreno, L. 2011. Chemical composition and antimicrobial activity of oregano (Lippia palmeri S. Wats) essential oil. Revista Fitotecnia Mexicana. 34: 11-17.

33. Pasquali, M.; Piatti, P.; Gullino, M. L.; Garibaldi, A. 2006. Development of a real-time polymerase chain reaction for the detection of Fusarium oxysporum f. sp. basilici from basil seed and roots. Journal of Phytopathology. 154: 632-636.

34. Peñuelas-Rubio, O.; Arellano-Gil, M.; Verdugo-Fuentes, A. A.; Chaparro-Encinas, L. A.; Hernández Rodríguez, S. E.; Martínez-Carrillo, J. L.; Vargas-Arispuro, I. D. C. 2017. Extractos de Larrea tridentata como una estrategia ecológica contra Fusarium oxysporum radicis-lycopersici en plantas de tomate bajo condiciones de invernadero. Revista Mexicana de Fitopatología. 35: 360-376.

35. Ramírez-Mares, M. V.; Hernández-Carlos, B. 2015. Plant-derived natural products from the American continent for the control of phytopathogenic fungi: a review. Journal of Global Innovations in Agricultural and Social Sciences, 3: 96-118.

36. Rekah, Y.; Shtienberg, D.; Katan, J. 2000. Disease development following infection of tomato and basil foliage by airborne conidia of the soilborne pathogens Fusarium oxysporum f. sp. radicis-lycopersici and F. oxysporum f. sp. basilici. Phytopathology. 90: 1322-1329.

37. Reuveni, R.; Raviv, M.; Krasnovsky, A.; Freimam, L.; Medina, S.; Bar, A.; Orion, D. 2002. Compostinduces protection against Fusarium oxysporum in sweet basil. Crop Protection. 21: 583-587.

38. Riedy, W. J. 2012. Economic links in a local economy: chefs and farmers in Los Cabos, Mexico. PhD dissertation-San Diego State University. USA.

39. Ríos-Flores, J. L.; Torres-Moreno, M.; Cantú-Brito, J. E.; Hernández-Martínez, M. A.; Ruiz-García, Y. P.; Soto-Sánchez, M, J. 2010. Impacto de la composición, rendimientos y precios en la agricultura del estado de Baja California Sur, México de 1990 a 2006. Revista Chapingo Serie Zonas Áridas. 9: 153-165.

40. Ritz, C.; Baty, F.; Streibig, J. C.; Gerhard, D. 2015. Dose-response analysis using R. PLoS ONE, 10. Doi:e0146021.

41. Sánchez-Verdugo, C.; Lucero-Flores, J. M. 2012. Market niches of gourmet organic species. Centro de Investigaciones Biológicas del Noroeste. S. C. La Paz. México. p. 72.

42. Sharma, B.; Kumar, P. 2009. In vitro antifungal potency of some plant extracts against Fusarium oxysporum. International Journal of Green Pharmacy. 3: 63-65.

43. Sidharthan, V. K.; Aggarwal, R.; Surenthiran, N.; Shanmugam, V. 2018. Selection and characterization of the virulent Fusarium oxysporum $f$. sp. lycopersici isolate inciting vascular wilt of tomato. International Journal of Current Microbiology and Applied Sciences. 7: 1749-1756.

44. Singh, G. M.; Ali, S.; Akhtar, M.; Suraj, S. K. 2012. Efficacy of plant extracts in plant disease management. Agricultural Sciences. 3: 425-433.

45. Summerell, B. A.; Salleh, B.; Leslie, J. F. 2003. A Utilitarian approach to Fusarium identification. Plant Disease. 87: 117-128.

46. Toussaint, J. P.; Kraml, M.; Nell, M.; Smith, S. E.; Steinkellner, S.; Schmiderer, C.; Vierheilig, H.; Novak, J. 2008. Effect of Glomus mosseae on concentrations of rosmarinic and caffeic acids and essential oil compounds in basil inoculated with Fusarium oxysporum f. sp. basilici. Plant Pathology. 57: 1109-1116.

47. Watanabe, T. 2010. Pictorial Atlas of soil and seed fungi; morphologies of cultured fungi and key to species. $3^{\text {rd }}$ ed.; CRC press, Taylor \& Francis Group. London. p. 397.

\section{ACKNOWLEDGMENTS}

The authors are grateful to SAGARPA-CONACYT for the financial resource of the project 126183; to Martín Aguilar and Sofia Ramos, technicians of CIBNOR Phytopathology Laboratory; to D. Fischer for editorial services in English. 